\title{
Thrombin Stimulates Proliferation of Cultured Rat Aortic Smooth Muscle Cells by a Proteolytically Activated Receptor
}

\author{
C. A. McNamara, * I. J. Sarembock, * L. W. Gimple, * J. W. Fenton II, \$ S. R. Coughlin, ${ }^{3}$ and G. K. Owens" \\ Departments of * Medicine and "Physiology, University of Virginia, Charlottesville, Virginia 22908; ${ }^{*}$ Wadsworth Center for Laboratories \\ and Research, New York State Department of Health, Albany, New York 12201; and ${ }^{\S}$ Department of Medicine and Cardiovascular \\ Research Institute, University of California, San Francisco, California 94143
}

\begin{abstract}
Thrombin has been implicated in the stimulation of smooth muscle cell (SMC) proliferation that contributes to post angioplasty restenosis. The present studies demonstrated that human $\alpha$-thrombin was a potent and efficacious mitogen for cultured rat aortic SMC, stimulating an increase in ${ }^{3} \mathrm{H}$-thymidine incorporation, as well as an increase in cell number at 1 to 10 $\mathrm{nM}$ concentration. $\boldsymbol{\gamma}$-Thrombin, which is enzymatically active but lacks fibrinogen clotting activity, stimulated SMC mitogenesis but was $\sim 10$-fold less potent than $\alpha$-thrombin. In contrast, D-phenylalanyl-L-propyl-L-arginyl-chloromethyl ketone$\alpha$-thrombin, which lacked enzymatic activity, had no mitogenic effect. Diisopropylfluorophosphate- $\alpha$-thrombin failed to stimulate mitogenesis except at concentrations having equivalent enzymatic activity as that of $\alpha$-thrombin at its threshold for mitogenesis. Thus, thrombin-induced proliferation was dependent on enzymatic activity. A 14-residue peptide (SFLLRNPNDKYEPF) corresponding to amino acids 42 through 55 of the human thrombin receptor (Vu, T. K., D. T. Hung, V. I. Wheaton, and S. R. Coughlin, 1991. Cell. 64:1057-1068) had full efficacy in stimulating SMC proliferation. Reversing the first two amino acids of this peptide abolished mitogenic activity. Northern analysis demonstrated that SMC expressed a single mRNA species that hybridized to a labeled thrombin receptor cDNA probe. These findings indicate that $\alpha$-thrombin stimulates SMC proliferation via the proteolytic activation of a receptor very similar or identical to that previously identified. (J. Clin. Invest. 1993. 91:94-98.) Key words: restenosis • thrombin • mitogenesis • smooth muscle cell • cell culture
\end{abstract}

\section{Introduction}

Percutaneous transluminal coronary angioplasty is a commonly used and effective method for reestablishing adequate blood flow in stenosed coronary arteries. Despite a high early success rate, restenosis occurs in $~ 30-35 \%$ of patients by 6 mo (1). Smooth muscle cell (SMC) ${ }^{1}$ proliferation is known to con-

Address correspondence to C. A. McNamara, Department of Medicine, University of Virginia, Charlottesville, VA 22908. Address reprint requests to G. K. Owens, Ph.D., University of Virginia, Department of Physiology, Jordan Hall, Box 449, Charlottesville, VA 22908.

Received for publication 1 May 1992 and in revised form 7 August 1992.

1. Abbreviations used in this paper: DIP, diisopropylfluorophosphate; PDGF, platelet-derived growth factor; PPACK, D-phenylalanyl-L-propyl-L-arginyl-chloromethyl ketone; SFM, serum-free medium; SMC, smooth muscle cells.

The Journal of Clinical Investigation, Inc.

Volume 91, January 1993, 94-98 tribute to postangioplasty restenosis (2-5), and as such there has been extensive interest in identifying the factors that modulate SMC proliferation. The vascular injury induced by angioplasty results in activation of the coagulation cascade which can generate $\sim 140 \mathrm{nM}$ concentration of thrombin (6). The resultant thrombus can serve as a reservoir of active thrombin (7). Thus, thrombin may have a significant role in the mediation of postangioplasty restenosis. Consistent with this, Sarembock et al. (8) have recently demonstrated that r-hirudin (a specific thrombin inhibitor) reduced restenosis after angioplasty in a rabbit model of focal femoral atherosclerosis. Additionally, a number of studies (9-11), though not all (12), have demonstrated that thrombin is a potent mitogen for SMC as well as other mesenchymal-derived cells (13-15).

Vu et al. (16) and Rasmussen et al. (17) cloned a cDNA encoding a functional thrombin receptor that has a novel proteolytic mechanism of activation. Their data demonstrated a signaling mechanism by which thrombin cleaves its receptor's amino terminal region, exposing a new amino terminus that functioned as a tethered ligand to activate the receptor. This receptor is expressed on platelets, endothelial cells (16), and fibroblasts (17). If thrombin's effects as an SMC mitogen are mediated via a similar receptor mechanism, catalytic activity would be essential for mitogenesis. Indeed, catalytic activity is essential for thrombin induced mitogenesis in fibroblasts (13). However, Bar Shavit et al. reported that catalytic activity was not necessary for thrombin-induced stimulation of mitogenesis in bovine aortic SMC (9). Thus, at present, it is unclear whether the mitogenic effects of $\alpha$-thrombin in SMC are mediated by receptors that are functionally similar to or distinct from the cloned thrombin receptors.

The objectives of the present study were to determine whether thrombin was mitogenic for cultured SMC and, if so, to determine whether this effect: $(a)$ was blocked by r-hirudin; (b) required the catalytic activity of thrombin; and (c) was mediated by a receptor similar to the thrombin receptor identified by Vu et al. (16) and Rasmussen et al. (17).

\section{Methods}

\section{Cell culture}

SMCs from rat aorta and rabbit femoral arteries were cultured by a modification of the method of Owens et al. (18). Rat aortic SMCs were plated at an initial seeding density of $3 \times 10^{3} / \mathrm{cm}^{2}$ and rabbit cells at 5 $\times 10^{3} / \mathrm{cm}^{2}$ into 24 -well plates (Corning Glass Inc., Corning, NY) and grown to confluence in medium containing equal parts of Dulbecco's modified Eagle's medium (Gibco Laboratories, Grand Island, NY) and Ham's F-12 (Gibco Laboratories), supplemented with $10 \%$ fetal bovine serum (FBS; Hyclone Laboratories Inc., Logan, UT), $100 \mathrm{U} /$ $\mathrm{ml}$ penicillin, $100 \mu \mathrm{g} / \mathrm{ml}$ streptomycin, and $0.68 \mathrm{mM}$ L-glutamine (Sigma Chemical Co., St. Louis, MO), designated DF-10. At confluence, the culture medium was replaced with serum-free medium 
(SFM) containing equal parts Dulbecco's modified Eagle's medium and Ham's F-12 containing penicillin, streptomycin, L-glutamine, insulin $(0.5 \mu \mathrm{M}$; Sigma Chemical Co.), transferrin $(5 \mu \mathrm{g} / \mathrm{ml}$; Sigma Chemical Co.), and ascorbate ( $0.2 \mathrm{mM}$; Sigma Chemical Co.). This SFM formulation has been shown to maintain smooth muscle cells in an anabolic, quiescent state (18). After $4 \mathrm{~d}$ in SFM, culture medium was replaced and cultures were treated with the growth factor of interest.

Growth factors. Platelet-derived growth factor (PDGF)-BB (Upstate Biotechnology Inc., Lake Placid, NY) was used at a concentration of $10 \mathrm{ng} / \mathrm{ml}$. The PDGF-BB vehicle contained $10 \mathrm{mM}$ acetic acid and $2 \mathrm{mg} / \mathrm{ml}$ BSA. The thrombin vehicle was PBS. Hirudin (leech, recombinant, [Lys-47] - rHV2 variant; Sigma Chemical Co.) was used as the thrombin inhibitor.

\section{Thrombin preparations}

Human $\alpha$-thrombin was prepared and evaluated as previously described (19). Catalytically inactivated diisopropylfluorophosphate (DIP)- $\alpha$-thrombin and D-phenylalanyl-L-propyl-L-arginyl-chloromethyl ketone (PPACK)- $\alpha$-thrombin, as well as $\gamma$-thrombin were made from $\alpha$-thrombin (13). The $\alpha$-thrombin preparation used in the present study was $96.2,3.4$, and $0.4 \% \alpha$-, $\beta$-, and $\gamma$-thrombins, respectively, titrated to $88.4 \%$ active enzyme, and had a specific clotting activity of 3,500 kilo U.S. NIH units/g. The DIP-and PPACK- $\alpha$-thrombin possessed 0.18 and $0.00 \mathrm{kU} / \mathrm{g}$, respectively. The $\gamma$-thrombin consisted of $0.0,15.1$, and $84.9 \% \alpha$-, $\beta$-, and $\gamma$-thrombins, and was $84.5 \%$ active and had $8.2 \mathrm{kU} / \mathrm{g}$. The activation peptide SFLLRNPNDKYEPE and the control isomer FSLLRNPNDKYEPE were synthesized as described (16).

\section{$\left[{ }^{3} \mathrm{H}\right]$ Thymidine incorporation}

Cultures were pulsed with $\left[{ }^{3} \mathrm{H}\right]$ thymidine (New England Nuclear, Boston, $\mathrm{MA} ; 2-10 \mu \mathrm{Ci} / \mathrm{ml}$ ) at 0,24 , and $48 \mathrm{~h}$ after stimulation, and were harvested for assay of $\left[{ }^{3} \mathrm{H}\right]$ thymidine incorporation into TCA precipitable material at 24,48 , and $72 \mathrm{~h}$, respectively. Cultures were washed with PBS, incubated with $10 \% \mathrm{TCA}$ at $4^{\circ} \mathrm{C}$ and at room temperature, dissolved in $1.0 \mathrm{M} \mathrm{NaOH}$, placed in scintillation fluid (Ready-Safe; Beckman Instruments, Inc., Palo Alto, CA), and counted on a scintillation counter ( $\mathrm{Lkb}-\beta$; Beckman Instruments).

\section{Cell counts}

Cultures were washed with PBS, harvested into $1 \mathrm{ml}$ of trypsin/EDTA diluted in $0.9 \% \mathrm{NaCl}$ (Columbia Diagnostics Inc., Springfield, VA), placed in a vial containing $20 \mathrm{ml}$ of filtered saline, and counted using an Electrozone Celloscope (Particle Data, Inc., Elmhurst, IL).

\section{Northern analysis}

Total RNA and poly (A) + selected RNA were prepared using methods previously described $(20,21) .30 \mu \mathrm{g}$ of total or $3 \mu \mathrm{g}$ of poly $(\mathrm{A})+$ selected RNA were dissolved in RNA loading buffer (0.2 M 3-(4-Morpholino)propane sulfonic acid, $0.05 \mathrm{M}$ sodium acetate, $0.01 \mathrm{M}$ EDTA, $37 \%$ formaldehyde, $99 \%$ formamide), and electrophoresed for $4 \mathrm{~h}$ in $1.2 \%$ agarose gel containing $6.7 \%$ formaldehyde. The gel was rinsed with water and then neutralized in $20 \times$ sodium chloride sodium phosphate EDTA buffer for $30 \mathrm{~min}$ before being transferred to a nylon membrane (Micron Separations Inc., Westboro, MA) for $16 \mathrm{~h}$. The filter was exposed to an ultraviolet transilluminator for $90 \mathrm{~s}$, baked for 2 $h$ at $80^{\circ} \mathrm{C}$ in a vacuum oven, air dried, and stored. Prehybridization, hybridization, and washing protocols were performed as described (22) at $65^{\circ} \mathrm{C}$. The probe used in this assay was a cDNA fragment encoding transmembrane domains three through seven of the murine homologue of the previously described human thrombin receptor (16). The nucleotide sequence for the murine thrombin receptor has been deposited in the Genbank database with accession number L03529. The probe used spanned nucleotide 587 to 1281 .

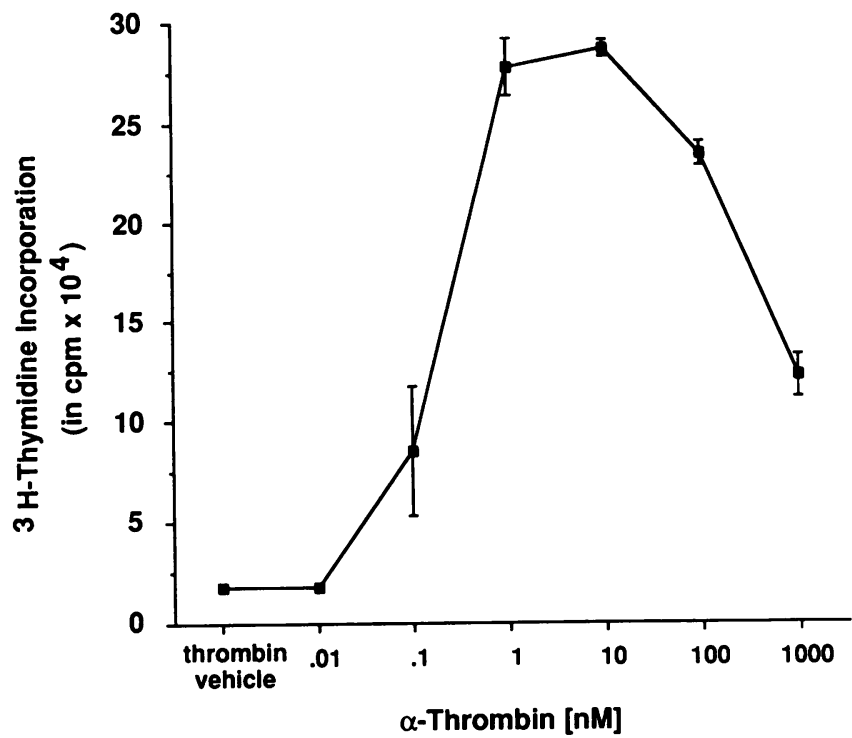

Figure 1. Thrombin induced a concentration dependent increase in DNA synthesis in cultured rat aortic SMC. Cells were plated at 3 $\times 10^{3} / \mathrm{cm}^{2}$ into 24-well plates, grown to confluence, growth arrested in a defined SFM, and stimulated with the thrombin vehicle (PBS) or increasing concentrations of $\alpha$-thrombin for $48 \mathrm{~h} .5 \mu \mathrm{Ci} / \mathrm{ml}$ of $\left[{ }^{3} \mathrm{H}\right]$ thymidine was added to the cultures at $24 \mathrm{~h}$ and the cells were harvested at $48 \mathrm{~h}$ for determination of $\left[{ }^{3} \mathrm{H}\right]$ thymidine incorporation as described in Methods.

\section{Results and Discussion}

Thrombin is a potent mitogen for aortic SMC in culture. As shown in Fig. 1, $\alpha$-thrombin was a very potent and efficacious mitogen for rat aortic SMCs in culture, eliciting a 10-15-fold increase in $\left[{ }^{3} \mathrm{H}\right.$ ] thymidine incorporation between 24 and $48 \mathrm{~h}$ after stimulation. $\alpha$-Thrombin stimulated a maximal mitogenic response at a concentration of 1-10 nM. Extremely high $\alpha$-thrombin concentrations resulted in a diminished response accompanied by loss of cells from the culture dish. The magnitude of the thrombin-induced growth response was equivalent to that elicited by PDGF-BB, a known potent SMC mitogen (23), and $60-80 \%$ as efficacious as $10 \%$ FBS (Fig. 2). Thrombin-induced increases in DNA synthesis were accompanied by a $60 \%$ increase in cell number (data not shown) indicating that thrombin was not simply increasing cell turnover. These results are consistent with previous studies demonstrating thrombin-induced mitogenesis in bovine aortic SMC (9) and SMC isolated from neonatal rat heart (11), and results from our laboratory with rabbit SMC (data not shown). In contrast, Berk et al. found that, whereas $\alpha$-thrombin stimulated many of the same early events as PDGF, such as increases in $[\mathrm{Ca} 2+]_{i}$, $\mathrm{pH}_{\mathrm{i}}, \mathrm{PtdInsP}_{2}$ hydrolysis, and c- fos mRNA in adult rat aortic vascular SMC (12), $\alpha$-thrombin did not stimulate cell division. Our studies were performed in a defined serum-free medium whereas those by Berk et al. were done in the presence of $0.4 \%$ fetal bovine serum. Indeed, the addition of $0.2 \%$ fetal bovine serum to our serum-free media resulted in a two- to fourfold reduction in the thrombin-stimulated increase in DNA synthesis (data not shown). The presence of serum could alter the phenotypic state of the cell, including changes in thrombin receptor number or responsiveness. Alternatively, serum is 


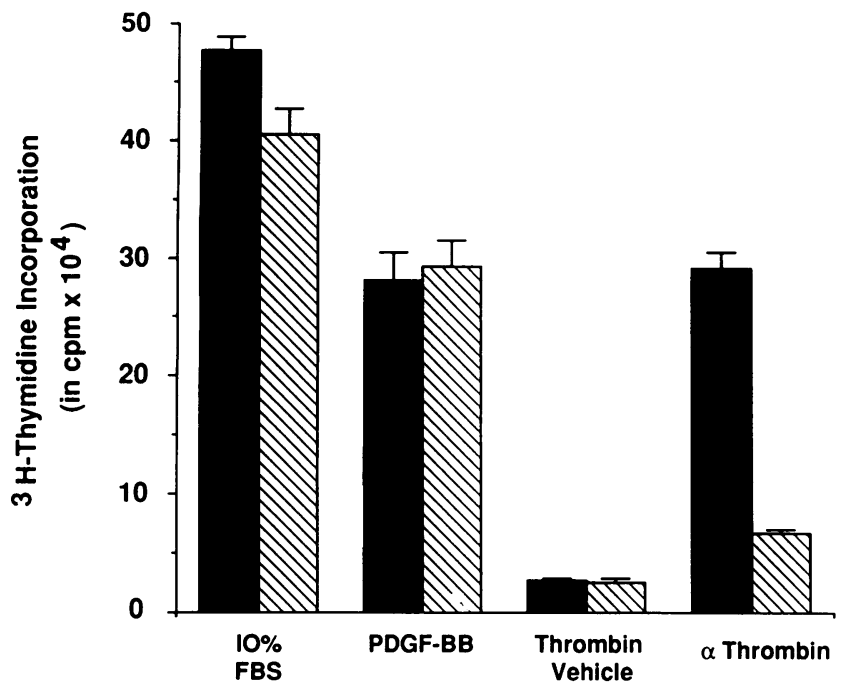

Figure 2. r-Hirudin inhibited $\alpha$-thrombin but not PDGF-BB and FBS-induced increases in DNA synthesis. Quiescent cells in 24-well plates were growth stimulated with $10 \%$ fetal bovine serum, PDGFBB $10 \mathrm{ng} / \mathrm{ml}$, thrombin vehicle (PBS), and $10 \mathrm{nM} \alpha$-thrombin in the absence and presence of hirudin (1:1 unit ratio). $5 \mu \mathrm{Ci} / \mathrm{ml}$ of $\left[{ }^{3} \mathrm{H}\right]$ thymidine was added at $24 \mathrm{~h}$ after stimulation and the cells were harvested for analysis of $\left[{ }^{3} \mathrm{H}\right]$ thymidine incorporation at $48 \mathrm{~h} . \mathbf{}$, Alone; $\bullet,+$ hirudin.

known to contain thrombin inhibitors such as antithrombin III (24). In our studies, using a defined serum-free medium, thrombin stimulation consistently elicited a potent and efficacious mitogenic response.

Thrombin-induced increases in DNA synthesis were evident at $24 \mathrm{~h}$ after stimulation. However, maximal effects were not observed until $48 \mathrm{~h}$ after stimulation (Fig. 3 ). In contrast, PDGF-BB-stimulated increases in DNA synthesis in rat aortic SMC are maximal at $24 \mathrm{~h}$ after stimulation (25). These results indicate that whereas $\alpha$-thrombin itself is mitogenic, it may also stimulate production of secondary growth factors by SMC. Thrombin is known to stimulate PDGF production by endothelial cells (26). Whereas SMC are known to produce a variety of growth factors (27-29), further studies are needed to determine the effects of thrombin on SMC growth factor production.

In additional experiments, r-hirudin, a specific thrombin inhibitor $(30,31)$, selectively inhibited $\alpha$-thrombin-induced mitogenesis in rat aortic SMC, but had no effect on the mitogenesis induced by $10 \%$ FBS or PDGF-BB (Fig. 2). These data confirm and extend previous results reported by Bar-Shavit et al. (9) who showed that hirudin inhibited thrombin-induced, but not serum-induced, mitogenesis.

Thrombin-induced VSMC proliferation is dependent on its active site. To determine whether thrombin-induced mitogenesis was dependent on its active enzymatic site, derivatives of thrombin with alterations of the active site and the binding site were tested (Fig. 4). PPACK- $\alpha$-thrombin has the active site blocked but can still bind the thrombin receptor via the anionbinding exosite. PPACK- $\alpha$-thrombin was not mitogenic even at concentrations 1,000 -fold greater than the concentration of $\alpha$-thrombin required to elicit a maximal mitogenic effect. Similarly, DIP- $\alpha$-thrombin, which has the active site blocked, failed

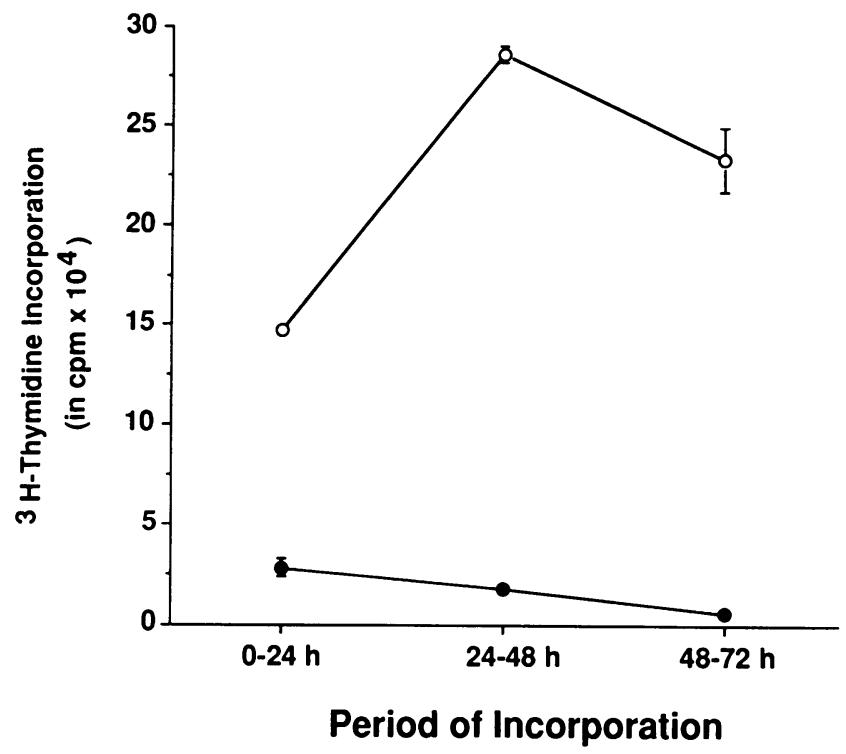

Figure 3. Thrombin stimulated a time-dependent increase in DNA synthesis in cultured rat aortic SMC. Quiescent cells in 24-well plates were treated with $10 \mathrm{nM} \alpha$-thrombin (O) or thrombin vehicle ( $\bullet$ ) at time $0.5 \mu \mathrm{Ci} / \mathrm{ml}\left[{ }^{3} \mathrm{H}\right]$ thymidine was added at 0,24 , or $48 \mathrm{~h}$ after stimulation and cells were harvested and assayed for $\left[{ }^{3} \mathrm{H}\right]$ thymidine incorporation $24 \mathrm{~h}$ later.

to stimulate DNA synthesis, except at extremely high concentrations of $>100 \mathrm{nM}$. At these high concentrations, the residual catalytically active $\alpha$-thrombin in the preparation $(\sim 0.1 \%)$ was equivalent to the threshold concentration at which $\alpha$-thrombin is mitogenic $(0.1 \mathrm{nM}) . \gamma$-Thrombin, which is disrupted in the anion-binding exosite but has an active cata-

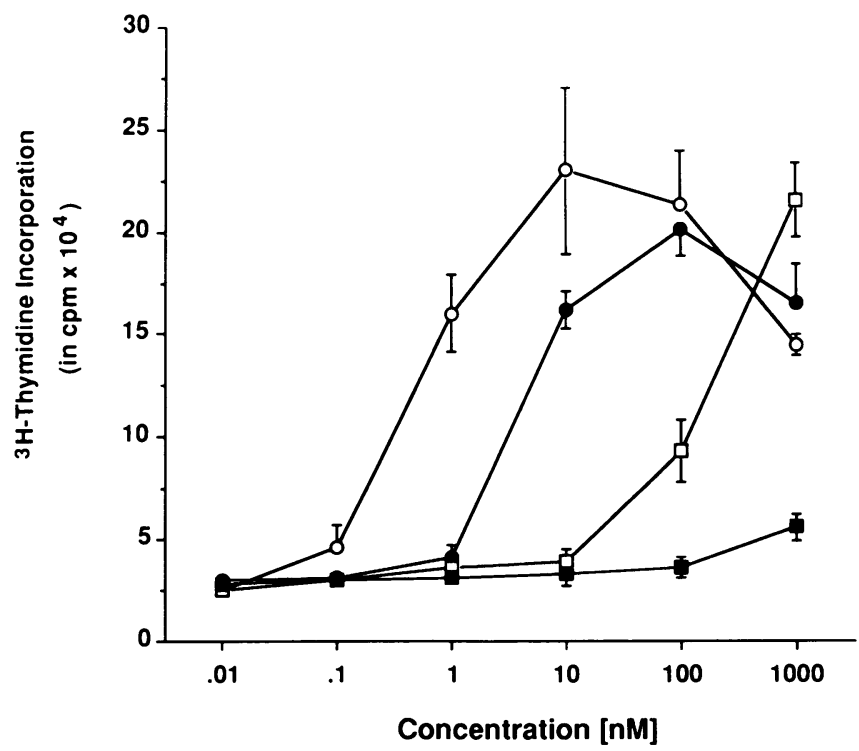

Figure 4. Catalytically inactive thrombin was not mitogenic for cultured rat aortic SMC. Quiescent cells in 24-well plates were stimulated with $\alpha$-thrombin (O), $\gamma$-thrombin (•), DIP- $\alpha$-thrombin ( $\square$ ), and PPACK- $\alpha$-thrombin $(\square) .5 \mu \mathrm{Ci} / \mathrm{ml}$ of $\left[{ }^{3} \mathrm{H}\right]$ thymidine was added at $24 \mathrm{~h}$ and cells were harvested at $48 \mathrm{~h}$ after stimulation for assay of $\left[{ }^{3} \mathrm{H}\right]$ thymidine incorporation. 
lytic site, was less potent than but had similar mitogenic efficacy as $\alpha$-thrombin. These data are consistent with the anion binding exosite of thrombin contributing to receptor binding (31). Our finding that the active site of thrombin was required for SMC mitogenesis is consistent with previous results demonstrating that the enzymatic activity of thrombin was required for thrombin-stimulated platelet activation $(16,32)$, fibroblast proliferation $(13,17)$, and stimulation of $\mathrm{Ca}^{2+}$ mobilization in oocytes expressing a transfected thrombin receptor (16). However, our results are in direct contrast to those of Bar-Shavit et al. (9) who reported that DIP-thrombin and PPACK-thrombin were mitogenic for bovine aortic SMC in culture. While our experiments were performed in serum-free medium, theirs were performed in the presence of $0.2 \%$ fetal bovine serum. Serum may interact with the catalytically inactive preparations to modulate their effects or may act synergistically with small amounts of residual catalytically active $\alpha$-thrombin in the preparations. Alternatively, cultured bovine SMC may express a different thrombin receptor or mechanism for thrombin-induced mitogenesis than rat aortic SMC.

Our results demonstrating that the thrombin active site was required for mitogenesis in SMC are consistent with the hypothesis that the mitogenic effects in rat aortic SMC are mediated by a receptor similar or identical to that cloned by $\mathrm{Vu}$ et al. (16) and Rasmussen et al. (17). To test this hypothesis further, rat aortic SMC were stimulated with the 14-amino acid synthetic thrombin receptor agonist peptide SFLLRNPNDKYEPF. This peptide has been shown to be capable of activating the human thrombin receptor in a xenopus oocyte system, stimulating platelet aggregation and degranulation (16), and stimulating mitogenesis in hamster lung fibroblasts (33). A peptide containing the sequence FSLLRNPNDKYEPF was tested as a control. Results demonstrated that the 14-amino acid receptor agonist peptide was as efficacious as $\alpha$-thrombin in stimulating proliferation of rat aortic SMC (Fig. 5), although at $\sim 1,000-$ 10,000 -fold the concentration of $\alpha$-thrombin. The difference in potency is likely related to the fact that the synthetic receptor agonist peptide is not tethered to the receptor, as is the ligand created by receptor cleavage with $\alpha$-thrombin. Additionally, it does not possess the full anion-binding exosite, which is known

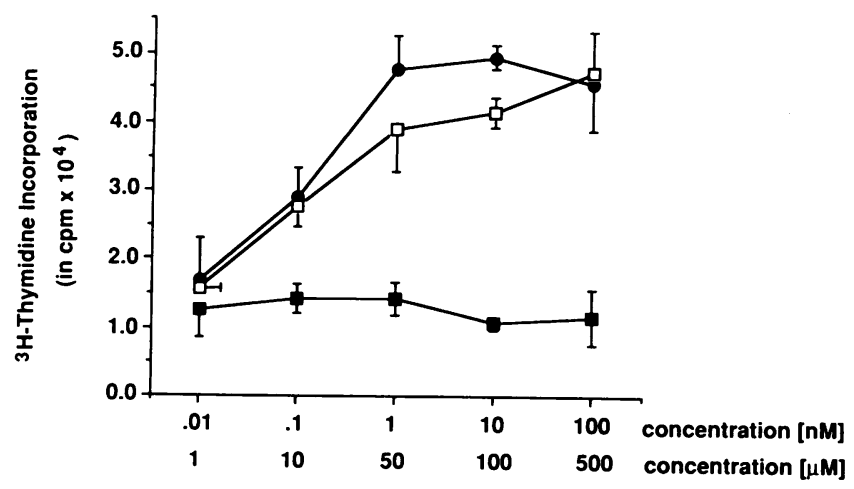

Figure 5. A thrombin receptor peptide stimulated mitogenesis in cultured rat aortic SMC. Quiescent cells in 96-well plates were stimulated with .01-100 nM $\alpha$-thrombin (๑), 1-500 $\mu \mathrm{M}$

SFLLRNPNDKYEPF (ם), and 1-500 $\mu \mathrm{M}$ FSLLRNPNDKYEPF (a). $5 \mu \mathrm{Ci} / \mathrm{ml}$ of $\left[{ }^{3} \mathrm{H}\right]$ thymidine was added at $24 \mathrm{~h}$ and cells were harvested for $\left[{ }^{3} \mathrm{H}\right]$ thymidine incorporation at $48 \mathrm{~h}$.

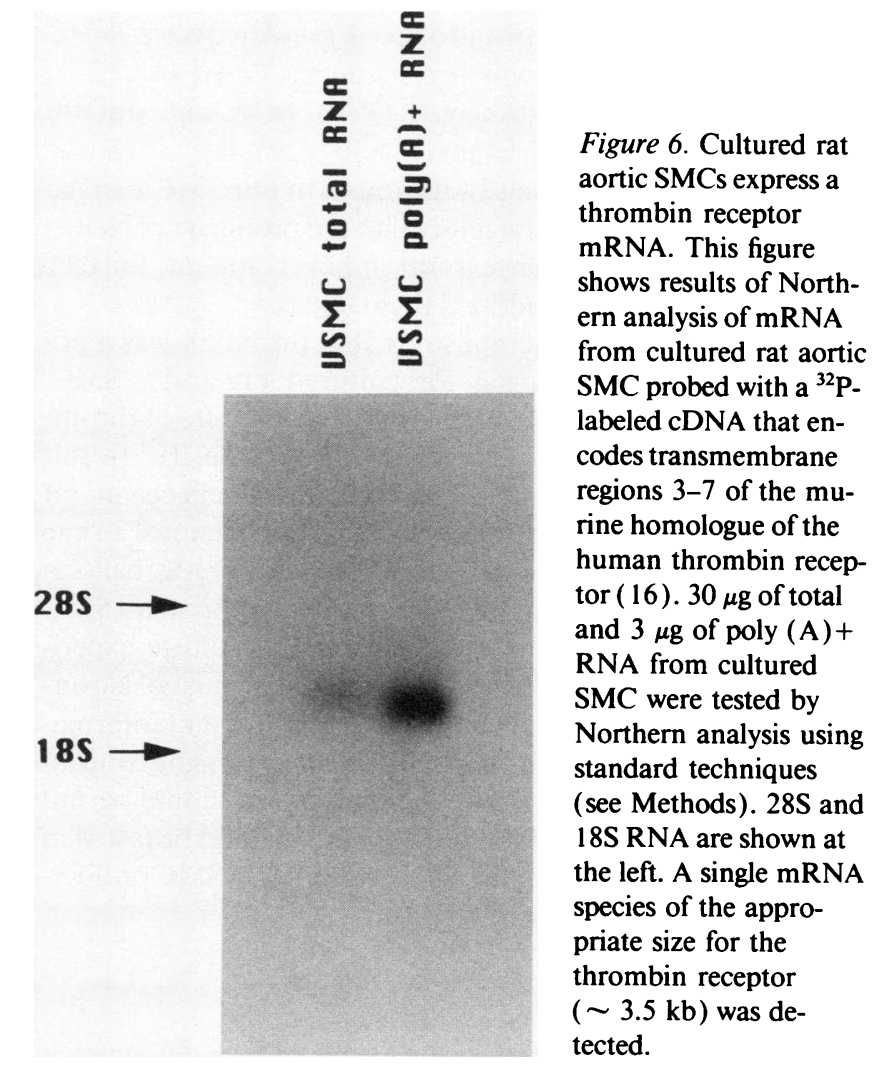

to be important for binding the thrombin receptor. The isomeric control peptide containing a reversal of the first two amino acids was not mitogenic. These results provide strong evidence that the active site of thrombin is essential for thrombin-induced mitogenesis in cultured rat SMC and that thrombin-induced mitogenesis in rat aortic SMC was mediated by a receptor that is identical or similar to the human thrombin receptor. Further confirmation of this was provided by Northern analysis which demonstrated that the cultured rat aortic SMC used in these studies expressed a single mRNA species of $\sim 3.5 \mathrm{~kb}$ which hybridized to a ${ }^{32} \mathrm{P}$-labeled murine homologue of the cloned human thrombin receptor (Fig. 6).

Thrombin modulates the effects of other growth factors. Vouret-Craviari et al. ( 34 ) reported that peptides derived from the newly exposed amino terminus of the hamster and human thrombin receptor activated phospholipase $\mathrm{C}$, modulated adenylate cyclase, and stimulated platelets to release serotonin but did not induce mitogenesis in hamster fibroblasts (CCL39 cells) unless the cells had been co-treated with fibroblast growth factor or other tyrosine kinase-dependent growth factors, such as PDGF, endothelial cell-derived growth factor, and insulin. Thrombin has also been shown to potentiate the mitogenic response of cultured fibroblasts to growth-promoting agents such as fibroblast growth factor, endothelial cellderived growth factor, insulin, prostaglandins, and serum (35). Our data clearly show that exogenous growth factors other than insulin, which is required for long-term survival of our cells in SFM, were not necessary for the peptide-induced mitogenic response in rat aortic SMC. However, we cannot rule out the possibility that thrombin and/or receptor peptide-induced growth in cultured SMC may be dependent on synergistic in- 
teraction with endogenously produced growth factors. SMC are known to produce growth factors such as PDGF-AA (27), transforming growth factor-beta (TGF- $\beta)(28)$, and smooth muscle cell-derived growth factor (SDGF) (29). It is thus possible that the mitogenic effects of thrombin in our SMC may be dependent on other growth factors that are produced constitutively by SMC or in response to thrombin treatment. Further studies will be needed to address these issues.

In summary, results demonstrate that thrombin was a potent and efficacious mitogen for cultured rat aortic SMC. Growth responses were dependent on the active site of thrombin and could be induced with a receptor peptide. This result suggests that the $\alpha$-thrombin-induced growth effects in rat SMC were mediated by a receptor similar or identical to the human thrombin receptor. The vascular response to balloon angioplasty is complex and involves processes other than SMC proliferation (2-5). Moreover, results of cell culture experiments cannot be directly extrapolated to events in vivo. Nevertheless, results of the present study provide important information about the mechanisms whereby thrombin might contribute to SMC proliferation after angioplasty, and should permit design of thrombin receptor antagonists that could be tested in vivo for their ability to limit thrombin-stimulated SMC proliferation and postangioplasty restenosis.

\section{Acknowledgments}

We thank Diane Raines and Mary McCanna for their excellent technical assistance and Bill Woolfolk for his editorial assistance.

This work was supported in part by the High Blood Pressure Research Training Grant HL-07355 (Dr. McNamara), National Institutes of Health RO1 HL-47849-01 (Dr. Sarembock), HL-38854 and HL-19242 (Dr. Owens), HL-13160 (Dr. Fenton), and HL-44907, HL43322, and HL-43801 (Dr. Coughlin).

\section{References}

1. Kent, K. M., L. G. Bentivoglio, P. C. Block, M. G. Bourassa, M. J. Cowley, G. Dorros, K. M. Detre, A. J. Gosselin, A. R. Gruentzig, S. F. Kelsey, et al. 1984. Long-term efficacy of percutaneous coronary angioplasty (PTCA): report from the National Heart, Lung, and Blood Institute PTCA Registry. Am. J. Cardiol. 53:27C-31C

2. Gravanis, M. B., and G. S. Roubin. 1989. Histopathologic phenomena at the site of percutaneous transluminal coronary angioplasty: the problem of restenosis. Hum. Pathol. 20:477-485.

3. Hanke, H., T. Strohschneider, M. Oberhoff, E. Betz, and K. R. Karsch. 1990. Time course of smooth muscle cell proliferation in the intima and media of arteries following experimental angioplasty. Circ. Res. 67:651-659.

4. Nobuyoshi, M., T. Kimura, H. Ohishi, H. Horiuchi, H. Nosaka, N. Hamasaki, H. Yokoi, and K. Kim. 1991. Restenosis after percutaneous transluminal coronary angioplasty: pathologic observations in 20 patients. J. Am. Coll. Cardiol. 17:433-439.

5. Steele, P. M., J. H. Chesebro, A. W. Stanson, D. R. Holmes, M. K. Dewanjee, L. Badimon, and V. Fuster. 1985. Balloon angioplasty: natural history of the pathophysiological response to injury in a pig model. Circ. Res. 57:105-112.

6. Walz, D. A., G. F. Anderson, R. E. Ciaglowski, M. Aiken, and J. W. Fenton II. 1985. Thrombin-elicited contractile responses of aortic smooth muscle. Proc. Soc. Exp. Biol. Med. 180:518-526.

7. Wilner, G. D., M. P. Danitz, M. S. Mudd, K.-H. Hsieh, and J. W. Fenton II. 1981. Selective immobilization of alpha-thrombin by surface-bound fibrin. $J$. Lab. Clin. Med. 97:403-411.

8. Sarembock, I. J., S. D. Gertz, L. W. Gimple, R. M. Owen, E. R. Powers, and W. C. Roberts. 1991. Effectiveness of recombinant desulphatohirudin in reducing restenosis after balloon angioplasty of atherosclerotic femoral arteries in rabbits. Circulation. 84:232-243.

9. Bar-Shavit, R., M. Benezra, A. Eldor, E. Hy-Am, J. W. Fenton II, G. D. Wilner, and I. Vlodavsky. 1990. Thrombin immobilized to extracellular matrix is a potent mitogen for vascular smooth muscle cells: nonenzymatic mode of action. Cell Regul. 1:453-463.
10. Graham, D. J., and J. J. Alexander. 1990. The effects of thrombin on bovine aortic endothelial and smooth muscle cells. J. Vasc. Surg. 11:307-313.

11. Huang, I.-L., and H. E. Ives. 1987. Growth inhibition by protein kinase C late in mitogenesis. Nature (Lond.). 329:849-850.

12. Berk, B. C., M. B. Taubman, K. K. Griendling, E. J. Cragoe, J. W. Fenton II, and T. A. Brock. 1991. Thrombin-stimulated events in cultured vascular smooth-muscle cells. Biochem. J. 274:799-805.

13. Glenn, K. C., D. H. Carney, J. W. Fenton II, and D. D. Cunningham. 1980. Thrombin active site regions required for fibroblast receptor binding and initiation of cell division. J. Biol. Chem. 255:6609-6616.

14. Chen, L. B., and J. M. Buchanan. 1975. Mitogenic activity of blood components. I. Thrombin and prothrombin. Proc. Natl. Acad. Sci. USA. 72:131135.

15. Pohjanpelto, P. 1978. Stimulation of DNA synthesis in human fibroblasts by thrombin. J. Cell Physiol. 95:189-194.

16. Vu, T. K., D. T. Hung, V. I. Wheaton, and S. R. Coughlin. 1991. Molecular cloning of a functional thrombin receptor reveals a novel proteolytic mechanism of receptor activation. Cell. 64:1057-1068.

17. Rasmussenn, U. B., V. Vouret-Craviari, S. Jallat, Y. Schlesinger, G. Pages, A. Pavirani, J.-P. Lecocq, J. Pouyssegur, and E. Van Obberghen-Schilling. 1991 cDNA cloning and expression of a hamster alpha-thrombin receptor coupled to $\mathrm{Ca} 2+$ mobilization. FEBS (Fed. Eur. Biochem. Soc.) Lett. 288:123-128.

18. Owens, G. K., A. Loeb, D. Gordon, and M. M. Thompson. 1986. Expression of smooth muscle-specific alpha-isoactin in cultured vascular smooth muscle cells: relationship between growth and cytodifferentiation. J. Cell Biol. 102:343352.

19. Fenton, J. W., II, M. J. Fasco, A. B. Stackrow, D. L. Aronson, A. M Young, and J. S. Finlayson. 1977. Human thrombins. Production, evaluation, and properties of alpha-thrombin. J. Biochem. (Tokyo). 252:3587-3598.

20. Chirgwin, J. M., A. E. Przybyla, R. J. MacDonald, and W. J. Rutter. 1979. Isolation of biologically active ribonucleic acid from sources enriched in ribonuclease. Biochemistry. 18:5924-5929.

21. Maniatis, T., E. F. Fritsch, and J. Sambrook. 1982. Molecular Cloning: A Laboratory Manual. Cold Spring Harbor Laboratory, Cold Spring Harbor, NY.

22. Church, G. M., and W. Gilbert. 1984. Genomic sequencing. Proc. Natl. Acad. Sci. USA. 81:1991-1995.

23. Ross, R., J. A. Glomset, B. Kariya, and L. Harker. 1974. A platelet-dependent serum factor that stimulates the proliferation of arterial smooth muscle cells in vitro. Proc. Natl. Acad. Sci. USA. 71:1207-1210.

24. Rosenberg, R. D. and J. S. Rosenberg. 1984. Natural anticoagulant mechanisms. J. Clin. Invest. 74:1-6.

25. Blank, R. S., and G. K. Owens. 1990. Platelet-derived growth factor regulates actin isoform expression and growth state in cultured rat aortic smooth muscle cells. J. Cell. Physiol. 142:635-642.

26. Harlan, J. M., P. J. Thompson, R. Ross, and D. F. Bowen-Pope. 1986. $\alpha$-Thrombin induces release of PDGF-like molecule(s) by cultured human endothelial cells. J. Cell Biol. 103:1129-1133.

27. Sejersen, T., C. Betsholtz, M. Sjolund, C.-H. Heldin, B. Westermark, and J. Thyberg. 1986. Rat skeletal myoblasts and arterial smooth muscle cells express the gene for the A chain but not the gene for the B chain (c-sis) of platelet-derived growth factor (PDGF) and produce a PDGF-like protein. Proc. Natl. Acad. Sci. USA. 83:6844-6848.

28. Majesky, M. W., V. Lindner, D. R. Twardzik, S. M. Schwartz, and M. A. Reidy. 1991. Production of transforming growth factor $\beta 1$ during repair of arterial injury. J. Clin. Invest. 88:904-910.

29. Morisaki, N., T. Kanzaki, T. Koshikawa, Y. Saito, and S. Yoshida. 1988. Secretion of a new growth factor, smooth muscle cell derived growth factor, distinct from platelet derived growth factor by cultured rabbit aortic smooth muscle cells. FEBS (Fed. Eur. Biochem. Soc.) Lett. 230:186-190.

30. Fenton, J. W., II. 1989. Thrombin interactions with hirudin. Semin. Thromb. Hemostasis. 15:265-268.

31. Fenton, J. W., II, G. B. Villanueva, F. A. Ofosu, and J. M. Maraganore. 1991. Thrombin inhibition by hirudin: how hirudin inhibits thrombin. Haemostasis. 21 (Suppl. 1):27-31.

32. Davey, M. G., and E. F. Luscher. 1967. Actions of thrombin and other coagulant and proteolytic enzymes on blood platelets. Nature (Lond.). 216:857858 .

33. Hung, D. T., T.-K. Vu, N. A. Nelken, and S. R. Coughlin. 1992. Thrombin-induced events in non-platelet cells are mediated by the unique proteolytic mechanism established for the cloned platelet thrombin receptor. J. Cell Biol. 116:827-832.

34. Vouret-Craviari, V., E. Van Obberghen-Schilling, U. B. Rasmussen, A. Pavirani, J.-P. Lecocp, and J. Pouyssegur. 1992. Synthetic alpha thrombin receptor peptides activate $G$ protein-coupled signaling pathways but are unable to induce mitogenesis. Mol. Cell. Biol. 3:95-102.

35. Zetter, B. R., T. T. Sun, L. B. Chen, and J. M. Buchanan. 1977. Thrombin potentiates the mitogenic response of cultured fibroblasts to serum and other growth promoting agents. J. Cell. Physiol. 92:233-240. 